\title{
Synthesis and Photovoltaic Properties of Novel Ruthenium(II) Sensitizers for Dye-sensitized Solar Cell Applications
}

\author{
Tae In Ryu, Myungkwan Song, Myung Jin Lee, Sung-Ho Jin, ${ }^{*}$ Sunwoo Kang, ${ }^{\dagger}$ Jin Yong Lee, ${ }^{\dagger}$ \\ Jae Wook Lee,,$^{\ddagger *}$ Chan Woo Lee, and Yeong-Soon Gal ${ }^{*}$
}

\author{
Department of Chemistry Education, Interdisciplinary Program of Ad Aanced Information and Display Haterials, \\ and Center for Plastic Information Sistem, Pusan National Cniversin. Busan 609-735. Korea. 'E-mail: shjinäapusan ac.kr \\ Department of Chemistry, Sunghumkwan Lniversitv, Sinton $4+40-746$, Korea

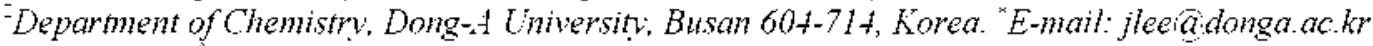 \\ Department of Chemistry, Liniversity of Llsan, C/san 680-749, Korea \\ "Polvmer Chemistry Lab, Kungil liniversitv, Havang 712-701, Korea \\ Received Julv 15, 2009, Accepted August 24, 2009
}

\begin{abstract}
Three heteroleptic ruthenium sensitizers, $\mathrm{Ru}(\mathrm{L})\left(\mathrm{L}^{\prime}\right)(\mathrm{NCS})_{2}\left[\mathrm{~L}=4,4^{\prime}\right.$-dicarboxylic acid-2,2'-bipvridine, Ru-T1: $\mathrm{L}^{\prime}=$ (E)-2-(4'-methy1-2,2'-bipyridin-4-y1)-3-(thiophen-2-yl)acrylonitrile, Ru-T2: $L^{2}=(E)-3-\left(5^{2}-\right.$ hexy $1-2,2^{\prime}-$ bithiophen-5yl)-2-(4'-methyl-2,2'-bipyridin-4-yl)acrylonitrile, and Ru-T3: $L^{3}=(E)-3-\left(5^{\prime \prime}\right.$-hexyl-2, $2^{\prime}: 5^{\prime}, 2^{\prime \prime}$-terthiophen-5-yl)-2(4'-1nethy l-2,2'-bipy'ridin-4-yl)acry lonitrile)], were synthesized and used as photosensitizers in nanocrystalline dyesensitized solar cells (DSSCs). The introduction of the 3-(5-hexyloligothiophen-5-yl)acry lonitrile group increased the conjugation length of the biprridine donor ligand and thus improved their molar absorption coefficient and light harvesting efficiency. DSSCs with the configuration of $\mathrm{SnO}_{2}: \mathrm{F}_{\mathrm{TiO}} / \mathrm{ruthenium}$ dye/liquid electroly te/Pt devices were fabricated using these Ru-T1 - T3 as a photosensitizers. Among the devices, the DSSCs composed of Ru-T2 exhibited highest power conversion efficiency (PCE) of $2.84 \%$ under AM $1.5 \mathrm{G}$ illumination $\left(100 \mathrm{~mW} / \mathrm{cm}^{2}\right)$.
\end{abstract}

Key Words: Ruthenium sensitizer. Oligothiophene. Dye-sensitized solar cell

\section{Introduction}

The effective conversion of solar energy' into electricity has become a very important issue in the last few years due to rising energy costs and demand. ${ }^{1}$ In recent vears, dye-sensitized solar cells (DSSCs) based on nanocrystalline $\mathrm{TiO}_{2}\left(\mathrm{nc}_{\mathrm{c}}-\mathrm{TiO}_{2}\right)$ films have received significant attention because of their high efficiency and low cost compared to those of silicon solar cells ${ }^{-3}$ In addition to the possibility of low production cost. another important advantage over conventional solar cells is the versatile design possibilities. such as production of flexible DSSCs with variable colors. In DSSCs, the sensitizing dye molecules must be chemically adsorbed on the porous $\mathrm{nc}^{-\mathrm{TiO}_{2}}$ surfaces and be capable of harvesting solar light ranging from the visible to the near- $\mathbb{R}$ regions. Up to now. the efficient sensitizers that have received the most research attention are ruthenium sensitizers ${ }^{4}$ which show effective charge separation at the metal to ligand (Ru-bpy) and ligand to metal (SCN-Ru) absorption bands in the visible solar light region. Although a variety of sensitizers, including metal-free organic dyes and non-ruthenium metal dyes. have been used. ruthenium polypyridine sensitizers exhibit the best performance to date..$^{5.8}$ With regard to the sensitizers. several ruthenium polypy ridine sensitizers. such as cis-dithiocyanato bis(4.4'-dicarbony-2.2'-bipy ridine) ruthenium(II) (N3) ${ }^{3 \cdot 3}$ its bis(tetrabutylammonium) salt (N719) ${ }^{8-9}$ and trithiocy'anato (4, 4', '4"-tricarbosy-2,2':6',2"-terpyridine)ruthenium(II) (black dye) ${ }^{+1.6}$ gave the best power conversion efficiency (PCE) of the examined dyes for DSSCs.

The ruthenium sensitizers underwent molecular engineering to maximize the PCE and thereby increase the molar absorption coefficient and reduce the number of protons on the complexes. 4.4'-Dicarbosylic acid-2,2'-bipyridine (dcbpy) has been considered the best anchoring ligand in Ru sensitizers. ${ }^{11}$ Replacement of one of the dcbpy anchoring ligands was reported by Grätzel and coworkers as a molecular engineering approach for increasing the molar absorption coefficient and the photocurrent density of the sensitizers. ${ }^{12-13}$ One strategy for increasing the light harvesting efficiency is to increase the conjugation length of the ligand. ${ }^{14 \cdot 16}$ For example, various types of alkyloligothiophene and vinylene units are introduced into the bipyridine (bpy) ligand as a pendant group.

In this paper. we design and synthesize of a new series of heteroleptic ruthenium sensitizers containing (E)-3-(5-hexyloligothiophen-5-yl)-2-(4'-methyl-2.2'-bipyridin-4-yl)acrylonitrile ligands $\left(L^{3}, L^{2}, L^{3}\right)$, in place of dcbpy, in a nuthenium sensitizers. The sensitizers exlubit intproved molar absorption coefficient while maintaining the required thermal and photostability. The new side chains are introduced on the bipyridine unit. in order to increase the conjugation length and thereby improve the light harvesting efficiency. We describe their thermal. optical. electrochemical properties, and photovoltaic properties.

\section{Expenimental Section}

Materials. Selenium dioxide ( $\mathrm{SeO}_{2}$ ). 4,4'-dimethyl-2,2'-bipyridine. sodium borohydride, sodium lydroxide, sodium carbonate. 18-crown-6. potassium cyanide, $\mathrm{N}$-bromosuccinimide (NBS). 2-thiophenecarboaldehyde. tetrakis(triphenylphospline) palla$\operatorname{dium}(0),[\mathrm{Ru}(p-c y m e n e) C l$ l] 2 - 4.4'-dicarboxylic acid-2.2'-bipyridine, ammonium thiocyanate were purchased from Aldrich 
Chemical Co. and TCI organic chemicals. These were used without further purification unless otherwise noted. Solvents were dried and purified by fractional distillation over sodium/ benzophenone and handled in moisture free atmosphere. $\mathrm{N} N$ dimethỵlformamide (DMF) was stirred with anhỵdrous $\mathrm{MgSO}_{4}$ for overnight and distilled under reduced pressure. Column chromatography was performed using silica gel (Merck. 250 430 mesh) and using Sephadex LH-20 (GE Healthcare).

Instnuments. ${ }^{\mathrm{H}} \mathrm{H}-\mathrm{NMR}$ spectra were recorded in $\mathrm{CDCl}_{3}$ on a Varian Mercury 300, and chemical shifts were recorded in ppm. The absorption spectra were measured using a Jasco V-570 UVvisible spectrometer. IR spectra were measured using a EQUINOX55 FTIR spectrometer. Thermal analyses were carried out on a Mettler Toledo TGA/SDTA 85 le. DSC 822e analyzer under a nitrogen atmosphere at a heating rate of $10^{\circ} \mathrm{C} / \mathrm{min}$. Density functional theory (DFT) calculations employing the Becke's three parameters employing Lee-Yang-Parr exchange functional (B3LYP) with $3-21 \mathrm{G}^{*}$ basis sets using a suite of Gaussian 03 programs. "Cyclic voltammetry (CV) was carried out with a Bioanalytical Systems CV-50 W voltametric analyzer at a potential scan rate of $100 \mathrm{mV} / \mathrm{s}$ in a $0.1 \mathrm{M}$ solution of tetrabutylammonium percllorate in anhydrous DMF. Each complexes. Ru-T1 T3 were absorbed on $\mathrm{TiO}_{2}$ coated FTO glass using electrode $\left(4 \mathrm{~cm}^{2}\right)$ by dipping the $\mathrm{TiO}_{2}$ coated FTO glass into complexes solution. A platinum wire was used as the counter electrode and an $\mathrm{Ag} /$ $\mathrm{AgNO}_{3}$ electrode was used as the reference electrode. All of the electrochemical experiments were performed in a glove box under an $\mathrm{N}_{2}$ atmosphere at room temperature.

Synthesis of 4-hydroxymethyl-4'-methyl-2,2'-bipyridine (1): $\mathrm{SeO}_{2}(9.8 \mathrm{~g}, 88.3 \mathrm{mmol})$ was added to a stirred suspension of $4.4^{\prime}$-dimethy l-2.2'-bipyridine ( $10 \mathrm{~g} .54 .3 \mathrm{mmol}$ ) in 1.4 -dioxane $(500 \mathrm{~mL})$ under an $\mathrm{N}_{2}$ atmosphere. The reaction mixture was stirred at reflux for $2+$ hr. After cooling to room temperature, the mixture was filtered and the solvent was removed in vacuum. The resulting solid was redissolved in chloroform and the suspension was filtered to remove selenium by products. After three successive dissolution and filtration treatments. crude product (7 g) was obtained. The resulting solid was suspended in methanol ( $75 \mathrm{~mL}$ ) and sodium borohydride ( $1.5 \mathrm{~g})$ in $\mathrm{NaOH}(0.2 \mathrm{M}$. $12.5 \mathrm{~mL}$ ) was added dropwise to the stirred mixture cooled on ice. The mixture was stirred at room temperature for $2 \mathrm{hr}$ and the methanol was removed in vacuum. The remaining aqueous suspension was diluted with saturated $\mathrm{Na}_{2} \mathrm{CO}_{3}$ solution $(30 \mathrm{~mL})$ and extracted with chloroform. The organic phase was dried and the solvent was evaporated. The crude product was purified by column chromatography (eluent: clloroform/methanol $=15: 1$ ) to give 4-hydroxy metyl-4'-methyl-2.2'-bipy ridine (1) $(8.3 \mathrm{~g}$. $77 \%$ ). ${ }^{\mathrm{H}} \mathrm{H}-\mathrm{NMR}\left(\mathrm{CDCl}_{3} . \hat{\mathrm{o}} \mathrm{ppm}\right) 8.61$ (d. $J=5.1 \mathrm{~Hz} . \mathrm{lH}$ ). 8.51 (d. $J=4.8 \mathrm{~Hz} .1 \mathrm{H}) .8 .32$ (s. $1 \mathrm{H}) .8 .20$ (s. $1 \mathrm{H}) .7 .30(\mathrm{~d} . J=4.5$ Hz, IH). $7.1+(\mathrm{d} J=4.5 \mathrm{~Hz}, \mathrm{IH}), 4.79$ (s. $2 \mathrm{H}), 2.44$ (s. $3 \mathrm{H})$. ${ }^{13} \mathrm{C}-\mathrm{NMR}\left(\mathrm{CDCl}_{3} . \grave{o} \mathrm{ppm}\right) 155.7 .155 .6,151.8 .148 .9,148.6$. $148.4,124.7 .122 .2,121.0,118.6 .62 .9 .21 .1$

Synthesis of +-bromomethyl-4'-methyl-2,2'-bipyridine (2): 4-Hydroxymetlyl-4'-metlyl-2.2'-bipyridine (1) (4.6 g. $23 \mathrm{mmol}$ ) was dissolved in $\mathrm{HBr}(48 \% .230 \mathrm{~mL})$ and $\mathrm{H}_{2} \mathrm{SO}_{4}(9 \mathrm{~mL})$ was added to the solution. The resulting solution was heated at reflux until all the starting materials had been consumed as monitored by $\mathrm{TLC}\left(\mathrm{Al}_{2} \mathrm{O}_{3}:\right.$ hexane/EtOAc. $\left.10: 90\right)$. After the reac- tion had gone to completion, the misture was cooled to room temperature and then water $(65 \mathrm{~mL})$ and dichloromethane $(65$ $\mathrm{mL}$ ) were added. The aqueous layer was brought to $\mathrm{pH} 8$ by adding with saturated $\mathrm{Na}_{2} \mathrm{CO}_{3}$ solution and extracted with dichloromethane $(50 \mathrm{~mL})$ until the organic layer was colorless. The combined organic layers were dried with anhydrous $\mathrm{MgSO}_{4}$ and the dichloromethane removed in vacuum to yield 4-bromomethyl-4'-methyl-2,2'-bipyridine (2) (5.89 g, 97\%). ${ }^{1} \mathrm{H}-\mathrm{NMR}$ $\left(\mathrm{CDCl}_{3} . \hat{o}\right.$ ppm) $8.50(\mathrm{~d} . J=4.8 \mathrm{~Hz}, 1 \mathrm{H}), 8.40(\mathrm{~d} . J=4.8 \mathrm{~Hz}$, lH) $8.29(\mathrm{~s} . \mathrm{lH}) .8 .10(\mathrm{~s} . \mathrm{lH}) .7 .16(\mathrm{~d} J=5.1 \mathrm{~Hz}, \mathrm{lH}) .6 .98(\mathrm{~d}$. $J=5.1 \mathrm{~Hz}, 1 \mathrm{H}), 4.32(\mathrm{~s}, 2 \mathrm{H}), 2.26(\mathrm{~s}, 3 \mathrm{H}),{ }^{12} \mathrm{C}-\mathrm{NMR}\left(\mathrm{CDCl}_{3}, \delta\right.$ ppm) 156.5. 154.9. 149.24. 148.6, 147.8, 146.7. 124.6, 123.1. $121.6,120.6 .30 .5 .20 .8$.

Synthesis of 2,2'-bipyidyl-4'-methyl-4-acetonitrile (3): Finely powdered $\mathrm{KCN}(6.5 \mathrm{~g} .0 .1 \mathrm{~mol})$ was added to 4-bromometlyyl-4'-metlyyl-2.2'-bipyridine (2) (2.5 g. $9.5 \mathrm{~nm}$ crown $-6(0.5 \mathrm{~g} .0 .19 \mathrm{mmol})$ in acetonitrile $(250 \mathrm{~mL})$, the misture stirred for $4 \mathrm{lur}$, diluted with water $(100 \mathrm{~nL})$ and extracted with dichloromethane $(4 \times 75 \mathrm{~mL})$. The combined organic layers were washed with water two more times and then dried over anlydrous $\mathrm{MgSO}_{4}$. After removal the solvent, the residue was subjected to purification by column chromatograph on silica gel (eluent : hexanes/EtOAC $=7: 3$ ) to give 2.2'-bipy ridyl-4'methyl-4-acetonitrile (3) (1.83 g. 92\%). ${ }^{1} \mathrm{H}-\mathrm{NMR}\left(\mathrm{CDCl}_{3}, \delta\right.$ ppm) $8.71(\mathrm{~d} . J=4.8 \mathrm{~Hz} .1 \mathrm{H}) .8 .55(\mathrm{~d}, J=4.8 \mathrm{~Hz}, 1 \mathrm{H}), 8.40(\mathrm{~s}$, lH). $8.26(\mathrm{~s}, \mathrm{lH}) .7 .37(\mathrm{~d}, J=4.8 \mathrm{~Hz}, \mathrm{IH}) .7 .19(\mathrm{~d} . J=4.5 \mathrm{~Hz}$.

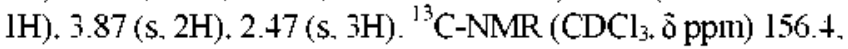
$15+2,149.9,149.0 .148 .3,139.9 .125 .2,122.5,122.1 .120 .5$, 23.4. 21.1

Synthesis of 2-bromo-5-fomylthiophene (4): In the absence of light. a solution of NBS ( $4.8 \mathrm{~g} .26 .75 \mathrm{mmol}$ ) in DMF (25 $\mathrm{mL}$ ) was added dropwies at room temperature to a well stirred solution of 2-thiophene aldelyde ( $3 \mathrm{~g}$. $26.75 \mathrm{~nm}$ ol) in DMF (25 mL). After a $40 \mathrm{hr}$ stirring. the solution was poured onto ice water and extracted several times with diethyl ether. The organic phase was combined. washed with water and the dried over anlyd drous $\mathrm{MgSO}_{4}$. The crude product was purified by column chromatography (eluent : chloroform/hexane $=1: 1$ ) to give 2bromo-5-formylthiophene (4) (4.19 g. 82\%). ${ }^{1} \mathrm{H}-\mathrm{NMR}\left(\mathrm{CDCl}_{\underline{3}}\right.$. $\delta \mathrm{ppm}) 9.61$ (s. 1H). $7.34(\mathrm{~s}, 1 \mathrm{H}) .7 .01(\mathrm{~s} .1 \mathrm{H}){ }^{12} \mathrm{C}-\mathrm{NMR}\left(\mathrm{CDCl}_{\mathrm{s}}\right.$. $\delta$ ppm) 181.5. 145.6, 136.7.131.3. 124.7.

Synthesis of 5-fomyl-5'-hexyl-2,2'-bithiophene (6): A nixture of 2-(tri-n-butylstannyl)-5-hexylthiophene (5) (8.06 g. $17.62 \mathrm{nmmol}$ ), 2-bromo-5-formylthiophene (4) (3.37 g. 17.62 numol), and tetrakis(tripheny lphosphine)palladium $(0)(0.2 \mathrm{~g})$ in dry toluene ( $165 \mathrm{~mL}$ ) was heated under $\mathrm{N}_{2}$. The reaction mixture was refluxed for 24 lur until precipitate formed. After cooling, the solid was collected by filtration and washed several times with hexane, methanol and water. The solid was purified by column chromatography (eluent : chloroform/hexane $=2: 3$ ) to give 5-formyl-5'-hexyl-2.2'-bithiophene (6) (2.6 g. 53\%). ${ }^{1} \mathrm{H}-$

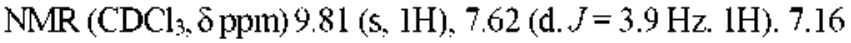
(d. $J=3.3 \mathrm{~Hz}, \mathrm{IH}) .7 .14(\mathrm{~d}, J=3.9 \mathrm{~Hz}, \mathrm{IH}) .6 .72(\mathrm{~d} . J=3.6 \mathrm{~Hz}$. lH). $2.79(\mathrm{t} . \mathrm{HH}) .1 .65(\mathrm{ml}, 2 \mathrm{H}), 1.31(\mathrm{~m} .7 \mathrm{H}) .0 .91(\mathrm{ml}, 3 \mathrm{H}){ }^{13} \mathrm{C}-$ $\mathrm{NMR}\left(\mathrm{CDCl}_{2}, \delta \mathrm{ppm}\right) 182.2,148.5,147.6,140.7,137.4,133.1$, $125.8,125.3 .123 .2,31.3,31.6,30.3,28.5,22.4,13.9$

Synthesis of 5-bromo-5'-fomyl-2,2'-bithiophene (7): In the absence of light. a solution of NBS (2.73 g. $15.34 \mathrm{mmol})$ in DMF 
$(20 \mathrm{~mL})$ was added dropwise at room temperature to a solution of 5-formyl-2.2'-bithiophene ( $2.98 \mathrm{~g} .15 .3+\mathrm{mmol}$ ) in DMF (20 $\mathrm{mL}$ ). After a $40 \mathrm{hr}$ stirring. the solution was poured onto iced water and extracted several times with dietlyl ether. The organic phase were combined. washed with water and dried to yield. after evaporation. The crude product was purified by column chromatography (eluent : chloroform/hexane $=1: 1$ ) to give 5 bromo-5'-formyl-2.2'-bithiophene (7) $(3.31 \mathrm{~g}, 79 \%)$. ${ }^{1} \mathrm{H}-\mathrm{NMR}$ (CDCl $3 . \hat{o}$ ppm) 9.84 (s. $1 \mathrm{H}), 7.65$ (d. $J=3.9 \mathrm{~Hz} .1 \mathrm{H}) .7 .17$ (d. $J=3.9 \mathrm{~Hz} \mathrm{IH}) .7 .09(\mathrm{~d} . J=3.9 \mathrm{~Hz}, \mathrm{lH}) 7.02(\mathrm{~d} J=3.9 \mathrm{~Hz}, \mathrm{lH})$.

Synthesis of 5-fomyl-5"-hexyl-2,2':5',2"-tenthiophene (8): A mixture of 2-(tri-n-butylstannyl)-5-hexylthiophene (5) (5.66 g. 12.4 mmol), 5-bromo-5'-formyl-2.2'-bithiophene (7) (3.38 g. $12 .+\mathrm{mmol}$ ). and tetrakis(triphenylphosphine)palladium(0) $(0.2 \mathrm{~g})$ in dry toluene $(20 \mathrm{~mL})$ was heated under $\mathrm{N}_{2}$. The reaction mixture was refluxed for 24 hr until precipitate formed. After cooling, the solid was collected by filtration and washed several times with hexane, methanol and water. The solid was purified by column chromatography (eluent : chloroform/hexane $=1: 2$ ) to give 5-formyl-5"-hexyl-2.2':5'.2"-terthiophene (8) $(2.5 \mathrm{~g}$. $56 \%$ ). ${ }^{\mathrm{H}} \mathrm{H}-\mathrm{NMR}\left(\mathrm{CDCl}_{3} . \delta \mathrm{ppm}\right) 9.84$ (s. $\left.1 \mathrm{H}\right), 7.64$ (d, $J=4.2$ Hz. $\mathrm{lH}$ ). 7.23 (d. $J=3.9 \mathrm{~Hz}, \mathrm{IH}) .7 .19$ (d. $J=3.9 \mathrm{~Hz}, \mathrm{IH})$. $7.02(\mathrm{~d} . J=3.9 \mathrm{~Hz} .2 \mathrm{H}), 6.70(\mathrm{~d} . J=3.6 \mathrm{~Hz} .1 \mathrm{H}), 2.79(\mathrm{t}, 1 \mathrm{H})$. $1.68(\mathrm{~m} .2 \mathrm{H}) .1 .33(\mathrm{~m}, 7 \mathrm{H}), 0.89(\mathrm{~m}, 3 \mathrm{H}) .{ }^{13} \mathrm{C}-\mathrm{NMR}\left(\mathrm{CDCl}_{3 .} \delta\right.$ ppm) 182.3. 147.04, 146.71. 141.38. 139.86, 137.29. 133.75 . $126.86 .125 .03,124.24,123.82 .123 .79,31.53,30.20 .29 .22$. $28.73,22.54,14.04$

Synthesis of (E)-2-(4'-methyl-2,2'-bipyridin-4-yl)-3-(thiophen-2-yl)acylonitrile $\left(\mathbf{L}^{1}\right)$ : A mixture of $2.2^{\prime}$-bipyridyl-4'methyl-4-acetonitrile (3) ( $1 \mathrm{~g}, 4.78 \mathrm{mmol}), 2$-thiophene carboaldehy de $(0.5+\mathrm{mL} .5 .73 \mathrm{mmol}$ ). piperidine ( $10 \mathrm{drops}$ ) and freshly distilled toluene $(20 \mathrm{~mL})$ were refluxed under $\mathrm{N}_{2}$ for $24 \mathrm{hr}$. After cooling, the solution was poured onto water and extracted several times with chloroform. The organic phase was dried with anhydrous $\mathrm{MgSO}_{4}$ and the solvent was evaporated. The crude product was purified by column chromatography (eluent : chloroform/hexane $=1 ; 3$ ) to give $(\mathrm{E})-2-\left(4^{\prime}-\right.$ methyl-2,2'-bipyridin4-yl)-3-(thiophen-2-yl)acrylonitrile ( $\left.\mathbf{L}^{1}\right)(0.95 \mathrm{~g} .66 \%)$. $\mathrm{H}-\mathrm{NMR}$ $\left(\mathrm{CDCl}_{3} . \delta \mathrm{ppm}\right) 8.75$ (d. $\left.J=5.4 \mathrm{~Hz} .1 \mathrm{H}\right), 8.67$ (d. $J=1.5 \mathrm{~Hz}$. 1H). $8.59(\mathrm{~d}, J=5.1 \mathrm{~Hz}, 1 \mathrm{H}) .8 .30(\mathrm{~s} .1 \mathrm{H}), 8.09(\mathrm{~s}, 1 \mathrm{H}) .7 .78$ (d. $J=3.6 \mathrm{~Hz} \mathrm{IH}) .7 .68(\mathrm{~d} . J=5.7 \mathrm{~Hz} . \mathrm{lH}) .7 .58(\mathrm{dd} J=2.1 \mathrm{~Hz}$ $J=5.25 \mathrm{~Hz} . \mathrm{lH}), 7.21(\mathrm{~m} .2 \mathrm{H}), 2.48(\mathrm{~s} .3 \mathrm{H}) .{ }^{13} \mathrm{C}-\mathrm{NMR}(\mathrm{CDCl}$. ò ppm) 156.7. 154.8. 149.8. 148.7. 148.1. 142.0. 137.1. 136.9. $134.2,131.8 .128 .0 .125 .0 .122 .0,120.0,117.0,115.9,105.4$, 21.0 .

(E)-3-(5'-hexỵl-2.2'-bithiophen-5-yl)-2-(4'-methỵl-2.2'-bipy ridin-t-yl)acrylonitrile $\left(\mathrm{L}^{2}\right)$ and $3-\left(5^{\prime \prime}\right.$-hexyl-2.2 $2^{\prime}, 5^{\prime}, 2^{\prime \prime}$-terthiophe-5-yl)-2-(4'-methỵl-2.2'-bipy ridin-4-yl)acrỵlonitrile ( $\left.\mathbf{L}^{3}\right)$ were synthesized with $2,2^{\prime}$-bipyridy l-4'-methyl-4-acetonitrile (3) and various structures of hexyloligothiophene aldehyde using a method similar to that of (E)-2-(4'-methyrl-2.2'bipy ridin- 4-y1)-3-(thiophen-2-yl)acry lonitrile $\left(\mathbf{L}^{1}\right)$.

(E)-3-(5'-Hexyl-2,2'-bithiophen-5-yl)-2-(4'-methyl-2,2'-bipyridin-4-yl)acrylonitrile ( $\left.\mathbf{L}^{2}\right):(0.6 \mathrm{~g} .54 \%)$. ${ }^{\mathrm{H}} \mathrm{H}-\mathrm{NMR}(300$ $\left.\mathrm{MHz}, \mathrm{CDCl}_{3} . \dot{o} \mathrm{ppm}\right) 8.73$ (d. $\left.J=5.1 \mathrm{~Hz}, \mathrm{lH}\right) .8 .65$ (d. $J=0.9$ Hz. $1 \mathrm{H}), 8.59(\mathrm{~d}, J=5.1 \mathrm{~Hz}, 1 \mathrm{H}) .8 .29(\mathrm{~d} . J=0.6 \mathrm{~Hz}, 1 \mathrm{H}) .8 .01$ (s. $1 \mathrm{H}), 7.60(\mathrm{~d}, J=4.2 \mathrm{~Hz} .1 \mathrm{H}), 7.55(\mathrm{dd} . J=2.1 \mathrm{~Hz} . J=5.25$ $\mathrm{Hz} \mathrm{IH}) .7 .16(\mathrm{~m}, 2 \mathrm{H}) .6 .76(\mathrm{~d} J=3.6 \mathrm{~Hz} . \mathrm{lH}) .2 .83(\mathrm{t} .2 \mathrm{H}) .2 .48$ (s. 3H), 1.71 (n. 2H). $1.35(\mathrm{~m}, 6 \mathrm{H}) .0 .91(\mathrm{~m}, 3 \mathrm{H}){ }^{12} \mathrm{C} \cdot \mathrm{NMR}$ ( $\mathrm{CDCl}_{3 .}$ ò ppm) 156.4. 154.9, 150.0. 148.6, 148.2. 145.0, 142.7 . $137.1,136.3,135.1,133.5,125.6,125.4,125.2,123.3,122.3$. $120.2,117.4,116.0 .103 .8,31.5,31.4,30.2,28.7,23.9,22.5$, $21.2,13.9$

(E)-3-(5"-Hexy]-2,2':5',2"-terthiophen-5-y) )-2-(4'-methỵl2,2'-bipylidin-4-yl)aclylonitrile $\left(\mathbf{L}^{3}\right)$ : $(0.6$ g. $50 \%)$. ${ }^{1} \mathrm{H}-\mathrm{NMR}$ $\left(300 \mathrm{MHz}, \mathrm{CDCl}_{3}, \hat{o}\right.$ ppm) 8.82 (s. $\left.1 \mathrm{H}\right), 8.70(\mathrm{~d}, J=5.1 \mathrm{~Hz}$, lH). $8.59(\mathrm{~d} . J=5.1 \mathrm{~Hz}, \mathrm{lH}) .8 .35(\mathrm{~s}, \mathrm{lH}) .8 .21(\mathrm{~s}, 1 \mathrm{H}) .7 .63(\mathrm{~d}$. $J=3.6 \mathrm{~Hz} \mathrm{lH}) .7 .55(\mathrm{~d} J=5.1 \mathrm{~Hz} \mathrm{lH}) .7 .26(\mathrm{~d} J=6 \mathrm{~Hz} \mathrm{lH})$. $7.22(\mathrm{~d}, J=3 \mathrm{~Hz}, 1 \mathrm{H}), 7.16(\mathrm{~d}, J=3.3 \mathrm{~Hz} .1 \mathrm{H}), 7.00(\mathrm{~d} . J=$ $3.9 \mathrm{~Hz}, 2 \mathrm{H}) .6 .68(\mathrm{~d} J=3.6 \mathrm{~Hz}, \mathrm{lH}), 2.78(\mathrm{t} .2 \mathrm{H}), 2.50(\mathrm{~s} .3 \mathrm{H})$. 1.67 (n. $2 \mathrm{H}) .1 .32(\mathrm{~m}, 6 \mathrm{H}), 0.89(\mathrm{~m} .3 \mathrm{H}) .{ }^{13} \mathrm{C}-\mathrm{NMR}\left(\mathrm{CDCl}_{3}, \hat{o}\right.$ ppm) 161.7. 154.7, 150.2, 147.2. 146.5, 144.4. 142.9. 139.4. $137.7,137.0,135.6,133.9,127.3 .126 .5,125.4,125.0 .124 .1$. $123.8,123.7 .122 .9,120.7 .117 .4,116.4 .103 .5,31.5,30.2$, $28.7,22.6,22.5,21.5,14.1,14.0$.

Synthesis of $\operatorname{Ru}\left(L_{)}\right)\left(L^{1}\right)(N C S)_{2}(R u-T 1)$ (where $L=4,4^{\prime}$-dicarboxylic acid-2,2'-bipylidine and $\mathrm{L}^{1}=(\mathrm{E})-2-\left(4^{\prime}-\right.$ methyl-2,2'bipyridin-t-y])-3-(thiophen-2-y])acrylonitrile: $[\operatorname{Ru}(p$-cymene) $\mathrm{Cl}_{2}=$ = $\left(51 \mathrm{mg} .0 .17 \mathrm{nmmol}\right.$ ) and $\mathrm{L}^{1}(51 \mathrm{mg} .0 .08 \mathrm{nmol}$ ) were dissolved in dry DMF $(50 \mathrm{~mL})$. The solution was heated at $80^{\circ} \mathrm{C}$ under $\mathrm{N}_{2}$ for 4 lur in the dark. And then $4.4^{\prime}$-dicarbosy lic acid$2.2^{\prime}$-bipy ridine ( $14 \mathrm{mg} .0 .06 \mathrm{mmol}$ ) was added. The reaction nixture was refluxed at $160^{\circ} \mathrm{C}$ for $t \mathrm{hr}$. To the resulting solution. ammonium thiocyanate $(76 \mathrm{mg} .1 \mathrm{mmol}$ ) was added and the reaction mixture was further heated at $130^{\circ} \mathrm{C}$ for $+\mathrm{hr}$. DMF was removed on a rotary evaporator under vacuun and water $(200 \mathrm{~mL}$ ) was added to induce the precipitate. The resulting solid was filtered off. washed with water and diethyl ether and dried under vacuum. The cnude product was dissolved in basic methanol (with TBAOH) and further purified on the Sephadex LH-20 with methanol as an eluent. The main band was collected. concentrated. and precipitated with acidic methanol $\left(\mathrm{HNO}_{3}\right)$ to obtain Ru(L)(L $\left.{ }^{l}\right)(\mathrm{NCS})$ ( $(\mathrm{Ru}-\mathrm{T1})(22 \mathrm{mg} .49 \%$ ). Anal. Calcd for $\mathrm{C}_{32} \mathrm{H}_{2 l} \mathrm{~N}_{7} \mathrm{O}_{4} \mathrm{~S}_{2}: \mathrm{C} .50 .25 \%: \mathrm{H}, 2.77 \%: \mathrm{N} .12 .82 \%: \mathrm{S} .12 .58 \%$ Found: C. $52.5 \%$. H. $4.7 \%$. N, 9.5\%. S. 6.5\%. Ru(L)(L $\left.\mathrm{L}^{2}\right)(\mathrm{NCS})=$ (Ru-T2) (where L = 4.4'-dicarboxy lic acid-2,2'-bipyridine and $\mathrm{L}^{2}=(\mathrm{E})-3-\left(5^{\prime}-\mathrm{he} x \mathrm{l}\right.$ l-2.2'-bithiophen-5-yl)-2-(4'-methyl-2,2'- bipyridin-t-yl)acrylonitrile and $\mathrm{Ru}(\mathrm{L})\left(\mathrm{L}^{3}\right)(\mathrm{NCS})=(\mathrm{Ru}-\mathrm{T} 3)$ (where $\mathrm{L}=4.4^{\prime}$-dicarboxylic acid-2.2'-bipyridine and $\mathrm{L}^{3}=(\mathrm{E})-3-\left(5^{\prime \prime}-\right.$ hexyl-2,2':5',2"-terthiophe-5-yl)-2-(4'-methyl-2.2'-bipy ridin4-yl)acrylonitrile) were synthesized and purified by a method similar to that used for $\operatorname{Ru}(\mathrm{L})\left(\mathrm{L}^{3}\right)(\mathrm{NCS})_{2}(\mathrm{Ru}-\mathrm{T1})$. $\mathrm{Ru}(\mathrm{L})\left(\mathrm{L}^{2}\right)$ (NCS) 2 (Ru-T2) (33 mg, 31\%). Anal. Calcd for $\mathrm{C}_{4} \mathrm{H}_{35} \mathrm{~N}_{7} \mathrm{O}_{4} \mathrm{~S}_{4}$ : C. $54.18 \%$ : H. $3.79 \%$ : N. 10.53\%: S. $13.78 \%$. Found: C. $50.3 \%$ : H. 3.9\%: N. 11.1\%: S. 8.3\%. Ru(L)(L $\left.\mathrm{L}^{3}\right)(\mathrm{NCS})$ (Ru-T3) (0.1 g. $53 \%$ ). Anal. Calcd for $\mathrm{C}_{46} \mathrm{H}_{2}: \mathrm{N}_{7} \mathrm{O}_{4} \mathrm{~S}_{5}: \mathrm{C} .54 .53 \%: \mathrm{H} .3 .68 \% \mathrm{~N}$. $9.68 \%$. S, $15.82 \%$, Found : C, $51.7 \%, \mathrm{H}, 4.2 \%$, N, $9.6 \%$, S. $9.7 \%$.

DSSC fablication. DSSC was fabricated using $\mathrm{TiO}_{2}$ films made from Dy'esol titania paste (Dy'esol Ltd. Australia). In each case the Dyesol paste was coated on the titanium(IV) isopropoxide pretreated FTO glass using a doctor blade technique. The paste on the FTO was then anmealed at $450^{\circ} \mathrm{C}$ for $30 \mathrm{~min}$ to produce a $13 \mu \mathrm{m}$ thick nanocrystalline $\mathrm{TiO}_{2}$ film. unless otherwise specified. The annealed film was inpregnated with RuT1 $\sim$ T3 $(0.5 \mathrm{~nL})$ in DMF for 24 lur at room tenperature. Each dye-coated film was soaked in DMF for $3 \mathrm{hr}$ to remove unatta- 
ched dye molecules and then in absolute ethanol for $2 \mathrm{hr}$ to remove DMF. The resulting ruthenium sensitizer-coated $\mathrm{TiO}_{2}$ film was washed with ethanol and then used to fabricate the DSSC according to the procedure reported elsewhere. ${ }^{18}$ The redox electrolyte solution for a DSSC consisted of $0.05 \mathrm{M} \mathrm{I}_{\text {. }}$. $0.1 \mathrm{M}$ Lil. 0.6 M 1.2-dimethyl-3-hexylimidazolium iodide. and $0.5 \mathrm{M}+$-tert-butylpy ridine in 3-methoxy propionitrile. The active areas of dye-coated $\mathrm{TiO}_{2}$ films were measured by an image analy sis program equipped with a digital microscope camera (Moticam 1000). The performance of DSSCs were measured using a calibrated AM 1.5 G solar simulator (Orel $300 \mathrm{~W}$ simulator. models 81150 ) with a light intensity of $100 \mathrm{~mW} / \mathrm{cm}^{2}$ adjusted using a standard PV reference cell $(2 \mathrm{~cm} \times 2 \mathrm{~cm} \mathrm{mono-}$ crystalline silicon solar cell calibrated at NREL. Colorado. USA) and a computer-controlled Keitluey 236 source measure unit.

The PCE ( $\eta$ ) of a solar cell given by

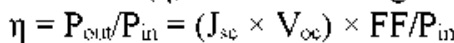

with $F F=P_{\text {max }} /\left(J_{s c} \times V_{o c}\right)=\left(J_{\max } \times V_{\text {max }}\right) /\left(J_{3 c} \times V_{\infty}\right)$. where $P_{\text {out }}$ is the output electrical power of the device under illumination. and $\mathrm{P}_{\text {ix }}$ is the intensity of incident light (e.g. in W/ $\mathrm{m}{ }^{2}$ or $\left.\mathrm{mW} / \mathrm{cm}^{2}\right) . V_{o c}$ is the open-circuit voltage. $J_{s c}$ is the short-circuit current density, and fill factor $(\mathrm{FF})$ is calculated from the values of $\mathrm{V}_{\mathrm{oc}} \mathrm{J}_{3 \mathrm{c} .}$ and the maximum power point. $\mathrm{P}_{\max }$. All fabrication steps and characterization measurenents were carried out in an ambient enviromment without a protective atmosphere. While measuring the current density-voltage $(\mathrm{J}-\mathrm{V})$ curves for DSSCs. a black mask was used and only the effective area of the cell was exposed to light irradiation. The data reported in this paper was confirmed by making each device more than 5 times.

\section{Results and Discussion}

The electronic and optical properties of nuthenium sensitizers can be controlled by modifying the main ligand's chenical structure. To adjust the highest occupied molecular orbital (HOMO) and lowest unoccupied molecular orbital (LUMO) energy levels and control the formation of amorphous morphology of the ruthenium sensitizers with the aim of improving the photovoltaic performance, we first synthesized heteroleptic ruthenium sensitizers introducing the 3-(5-hexyloligothiophen-5-yl)acrylonitrile into the bipy ridine backbone. The synthetic routes for the 2,2'-bipyridyl-4'-methyl-4-acetonitrile (3). 5-formyl-5'-hexyl2.2'-bithiophene (6) .5-formyl-5"-hexyl-2,2':5',2"-terthiophene (8), and three bipy ridyl-based ligands $\left(\mathbf{L}^{1}, \mathbf{L}^{2}, \mathbf{L}^{3}\right)$ are described in Scheme 1 . The addition of the single 3-(5-hexyloligothiophen-5-yl)acry lonitrile group into the bipyridine chain was expected to tune the HOMO and LUMO energy levels of the

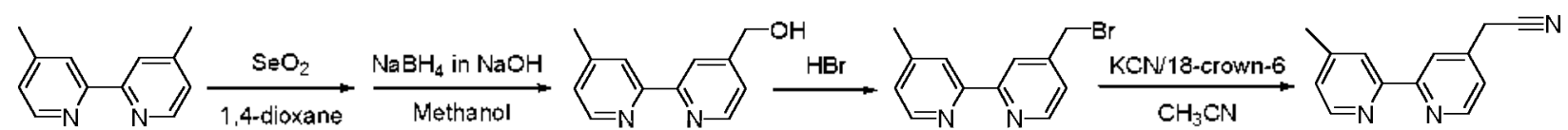

(1)

(2)

(3)<smiles>CC(C)(C)c1ccc([SnH3])s1</smiles>

(4)<smiles>O=Cc1ccc(-c2ccc(-c3ccccc3)s2)s1</smiles>

(6)

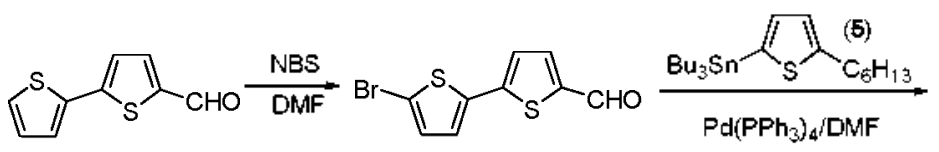

(7)

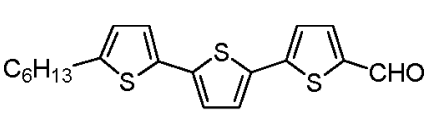

(8)

(3) +<smiles>Cc1ccnc(-c2cc(/C(C#N)=C\c3cccs3)ccn2)c1</smiles><smiles>CCCCCc1ccc(-c2ccc(/C=C(/C#N)c3ccnc(-c4cc(C)ccn4)c3)s2)s1</smiles>

(6)

(3) +<smiles>CCCCCc1ccc(-c2ccc(-c3ccc(/C=C(/C#N)c4ccnc(-c5cc(C)ccn5)c4)s3)s2)s1</smiles>

(8)

Scheme 1. Synthetic Routes for Ligands. 
ruthenium sensitizers as well as amorphous nature due to heteroleptic molecular structures. 4-Hydroxymethyl-4'-methyl$2.2^{\prime}$-bipyridine (1) was synthesized by oxidation reaction of 4,4'-dimethyl-2,2'-bipyridine. The bromomethyl compound (2) was synthesized by the bromination in acidic solvent. 2.2'-Bipyridyl-4-methyl-4-acetonitrile (3) was synthesized by the $\$ \times 2$ reaction of potassium cranide in acetonitrile and catalyzed with 18-crown-6. 2-Bromo-5-formy lthiophene (4) and 2-(trin-butylstannyl)-5-hexylthiophene (5) were synthesized according to literature procedures. ${ }^{19}$ 2-Bromo-5-formylthiophene (4) and 5-bromo-5'-formyl-2.2'-bithiophene (7) were synthesized by the bromination reaction of 2-thiophenealdehyde and 5-formyl-2.2'-bithiophene with NBS in DMF. 5-Formyl-5'hexyl-2.2'- bithiophene (6) and 5-formyl-5"-hexyl-2.2':5',2"terthiophene (8) were sy nthesized by the Stille cross-coupling reaction of stanny lthiophene (5) with compounds $(4)$ and $(7)$. The newly designed. heteroleptic ligands. $\mathbf{L}^{1}, \mathbf{L}^{2}$, and $\mathbf{L}^{3}$. were synthesized by the Knoevenagel reaction with single condensation of hexyloligothiophene aldehydes and 2.2'-bipyridỵl4'-methyl-4-acetonitrile (3).

Scheme 2 shows the details of the synthetic methods for the preparation of heteroleptic sensitizers of the type $\left[\mathrm{Ru}(\mathrm{L})\left(\mathrm{L}^{\prime \prime}\right)\right.$ (NCS) 2 ], where $\mathrm{L}=4,4^{\prime}$-bis(carboxylic acid)-2,2'-bipyridine and $\mathrm{L}^{\mathrm{x}}=\mathrm{L}^{3}, \mathrm{~L}^{2}$. and $\mathrm{L}^{3}$. Reaction of dichloro(p-cymene)nithenium(II) dimer in DMF at $80^{\circ} \mathrm{C}$ with $\mathrm{L}^{\circ}$ gave a mononu- clear complexes. In this step, the substituted bipy ridine ligands were coordinated to the ruthenium center with cleavage of the double chloride-bridged structure of the dimeric complex. ${ }^{2(i)}$ The heteroleptic dicluloro complexes were prepared by reacting the monomuclear $\mathrm{Ru}\left(\mathrm{L}^{\circ}\right) \mathrm{Cl}$ (cymene)]Cl complex with $\mathrm{L}^{\text {" under }}$ reduced light at $160^{\circ} \mathrm{C}$. The $\left[\mathrm{Ru}(\mathrm{L})\left(\mathrm{L}^{\mathrm{x}}\right)(\mathrm{Cl})\right.$ )] complex was reacted with a 20 -fold excess of ammonium thiocyanate ligand to obtain the $\left[\mathrm{Ru}(\mathrm{L})\left(\mathrm{L}^{\mathrm{x}}\right)(\mathrm{NCS})_{2}\right]$ sensitizers. Ru-T1 $\sim \mathbf{T 3}$.

$\mathbf{R u}-\mathbf{T 1} \sim \mathbf{T 3}$ are very weakly soluble in common organic solvents such as acetonitrile. ethanol. methanol and dichloromethane. However. Ru-T1 $\sim$ T3 were sufficiently soluble in DMF and DMSO for their NMR. cyclic voltammetry, and electrooptical properties to be measured. Among Ru-T1 $\sim$ T3, the solubility of $\mathbf{R u}-\mathbf{T} 2$ was higher than that of $\mathbf{R u}-\mathbf{T 1}$ and $\mathbf{R u}-\mathbf{T 3}$. The structures of the intermediates. ligands. and Ru-T1 $\sim$ T3 were confirmed by ${ }^{1} \mathrm{H}-,{ }^{12} \mathrm{C}-\mathrm{NMR}$ spectroscopy and elemental analysis.

In general, the ${ }^{\text {l}} \mathrm{H}-\mathrm{NMR}$ spectra of the ligands show sharp signals in the aromatic region. whereas their corresponding Ru-T1 $\sim$ T3 exhibit slightly broader signals. The complicated multiple peaks in the ${ }^{l} \mathrm{H}$ NMR spectrum of Ru-T1 $\sim$ T3 indicated that the bipyridine and 3 -(5-hexyloligothiophen-5-yl) acry lonitrile moieties were magnetically nonequivalent. The small peak at $9.89 \mathrm{ppm}$ belongs to a portion of carboxy lic acid protons. suggesting that the bipy ridine ligand contains carboxy-<smiles>Cc1ccnc(-c2cc(/C(C#N)=C\c3cccs3)ccn2)c1</smiles>

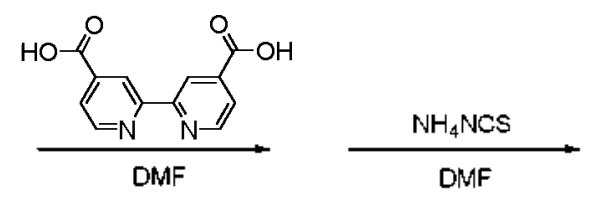

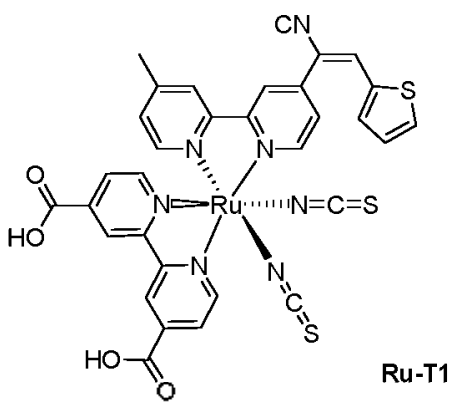<smiles>CCCCc1ccc(-c2ccc(/C=C(/C#N)c3ccnc(-c4cc(C)ccn4)c3)s2)o1</smiles>

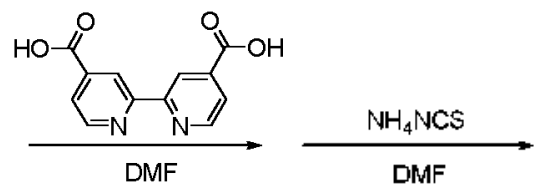

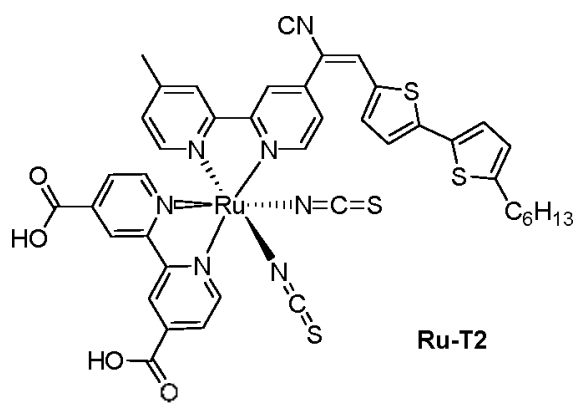<smiles>CCCCc1ccc(-c2ccc(-c3ccc(/C=C(/C#N)c4ccnc(-c5cc(C)ccn5)c4)s3)s2)o1</smiles>

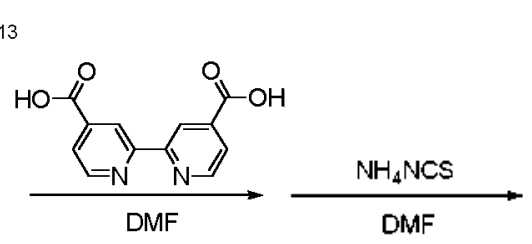

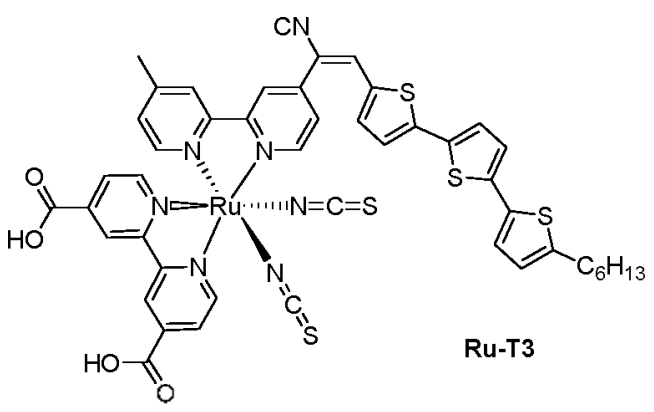

Scheme 2. Synthetic Routes for Ru Sensitizers. 


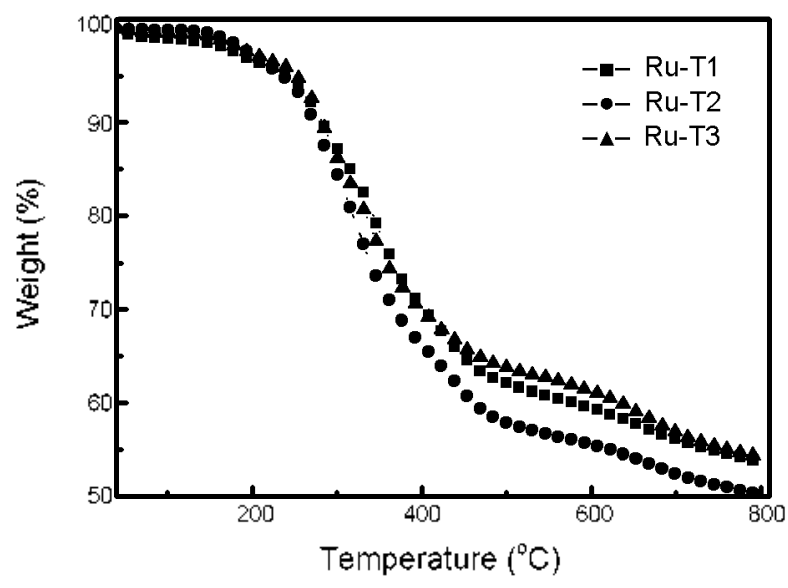

Figure 1. TGA thermograms of Ru-T1, Ru-T2, and Ru-T3.

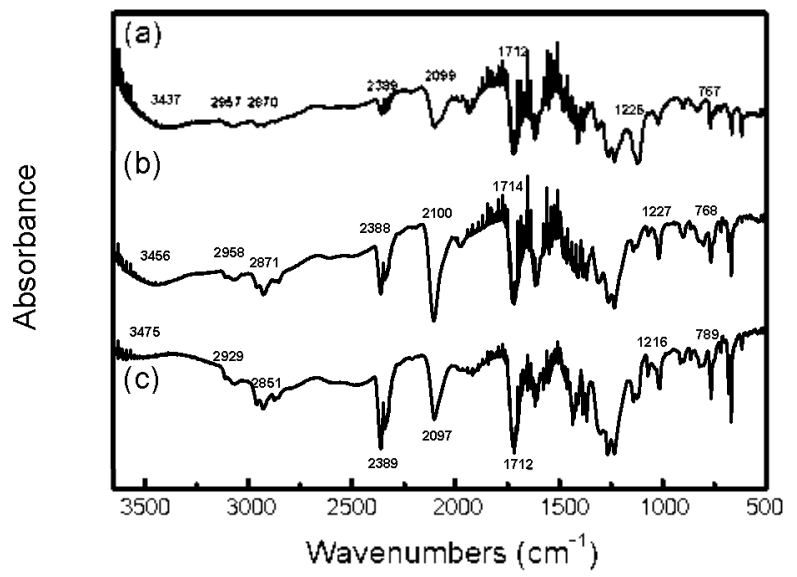

Figure 2. FTIR spectra of Ru-T1 (a), Ru-T2 (b), and Ru-T3 (c), obtained using a solid sample.

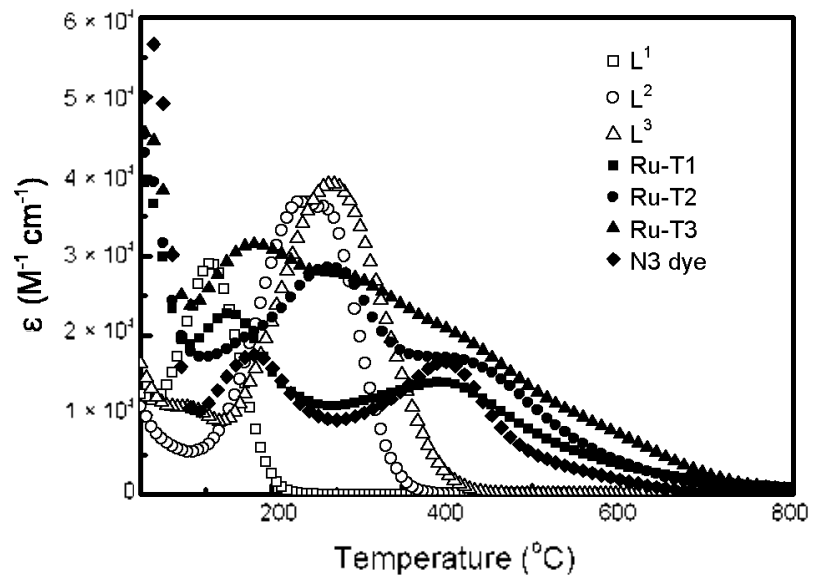

Figure 3. UV-visible absorption spectra of $L^{\prime}, L^{*}, L^{*}, R u-T 1, R u-T 2$, Ru-T3, and N3 in DMF.

lic acid groups. The thermal properties of $\mathbf{R u}-\mathbf{T} \mathbf{T} \sim \mathbf{T} 3$ were determined by thermal gravimetric analysis (TGA) under $\mathrm{N}_{2}$ atmosphere and the TGA thermograms are shown in Figure 1. The TGA thermograms of Ru-T1 $\sim$ T3 revealed a $5 \%$ weight loss at 224.231 , and $247^{\circ} \mathrm{C}$. respectively.

IR spectroscopy has been shown to be a powerful tool to extract structural information about Ru-T1 $\sim$ T3. Figure 2 shows the typical IR spectra of Ru-T1 $\sim$ T3 powders using FTIR in the $3600-500 \mathrm{~cm}^{-1}$ range. Ru-T1 $\sim$ T3 showed a weak and broad band at $3456 \mathrm{~cm}^{-1}$ due to carbosylic acid group. The intense bands at 1226.1227 , and $1216 \mathrm{~cm}^{-1}$ were assigned to the singlebonded carbon-oxygen in Ru-T1 T3. respectively. The methyl stretching modes were located at $2850 \mathrm{~cm}^{-1}$ and $2950 \mathrm{~cm}^{-1}$. together with a weak thiocyanate group at $2389 \mathrm{~cm}^{-1}$. The UVvisible absorption spectra of $\mathrm{L}^{1} . \mathrm{L}^{2}$, and $\mathrm{L}^{3}$ in DMF solution are displayed in Figure 3 . The $\lambda_{\max }$ values for $\mathrm{L}^{1} . \mathrm{L}^{2}$, and $\mathrm{L}^{3}$ were 354.431 , and $452 \mathrm{~nm}$, respectively, which were assigned to the $\pi-\pi^{*}$ transition. The absorption maximum of $\mathrm{L}^{3}$ was redshifted by $21 \mathrm{~nm}$ compared to $\mathrm{L}^{2}$. and by $98 \mathrm{~nm}$ relative to $\mathrm{L}^{3}$, which can be attributed to the increasing number of thiophene moieties in L ${ }^{3}$. The UV-visible absorption spectra of Ru-T1 $\mathbf{T 3}$ with $\mathbf{N} 3$ dye are also shown for comparison in Figure 3. The absorption spectnum of Ru-T1 exhibited three bands centered at $529 \mathrm{~lm} .368 \mathrm{~lm}$, and $301 \mathrm{~nm}$. By conparing this spectrum with those of $\mathrm{L}^{1}$ and the $\mathbf{N} \mathbf{3}$ dye. the absorption bands at $30 \mathrm{Imm}$ and $368 \mathrm{~nm}$ were assigned to the intra-ligand $\pi-\pi^{*}$ transitions of dcbpy and $\mathrm{L}^{1}$, respectively. The absorption band at $529 \mathrm{~nm}$ is characteristic of the MLCT transition which is one of the dominant factors for deternining the efficiency of sensitizers. The absorption spectnum of Ru-T2 also presented three bands centered at $551 \mathrm{~nm} .4+5 \mathrm{~nm}$. and $300 \mathrm{~nm}$. The $\hat{z}_{\max }$ values of the three bands in Ru-T2 were longer than those of Ru-T1, due to the longer conjugation length of ligand in the former. However. the absorption spectrum of Ru-T3 was different from that of Ru-T1 and Ru-T2. The absorption spectnum of Ru-T3 revealed two broad bands at $305 \mathrm{~nm}$ and $388 \mathrm{~nm}$ with a strong tailing at $800 \mathrm{~nm}$ due to three thiophene moieties in Ru-T3. The absorption and electrochemical properties of Ru-T1 $\sim \mathbf{T 3}$ and $\mathbf{N} 3$ are sunmarized in Table 1. The molar absorption coefficients of Ru-T1 $\sim \mathbf{T 3}$ at the $\lambda_{\max }$ wavelength in solution ranged from 30,400 to $45.600 \mathrm{M}^{-1} \mathrm{~cm}^{-1}$. Relatively high molar absorption coefficients can result in high efficiency because of the extended $\pi$-electron delocalization. The UV-visible absorption spectra of Ru-T1 T3 measured in DMF revealed that the lower energy MLCT band for Ru-T1 $\sim$ T3 was centered at 529.551 and $558 \mathrm{~nm}$ with a molar absorption coefficient of $14.1,16.8$ and $27.6\left(\times 10^{3} \mathrm{M}^{-1} \mathrm{~cm}^{-1}\right)$, respectively, and $\mathrm{N} 3\left(16.6 \times 10^{3} \mathrm{M}^{1} \mathrm{~cm}^{-1}\right.$ at $533 \mathrm{~nm}$ ) for comparison. The result suggests that the conjugation length of the ligand will affect the MLCT energy between the metal center and the anchoring ligand We therefore expected that the MLCT transition would be driven to a lower energy due to the extended conjugation length of the ligand in the metal complex, and that use of ruthenium sensitizers would produce a DSSC with a high photovoltaic performance. The higher light harvesting efficiency of Ru-T3 compared with Ru-T1 and RuT2 was attributed to the extended conjugation length of the ligand in the thiophene moiety.

$\mathrm{CV}$ was used to investigate the electrochenical behavior of Ru-T1 $\sim$ T3 and the HOMO and LUMO energy levels. The oxidation potentials of Ru-T1 $\mathbf{T 3}$ conplexes were well correlated with those of the respective donor groups. thiophene. bithiophene. and terthiophene. The HOMO values were calculated from $\mathrm{E}_{\mathrm{ox}}$ as $-5.01,-4.87$. and $-4.86 \mathrm{eV}$ for Ru-T1, Ru-T2, and Ru-T3, respectively. The LUMO energy level of 
Talle 1. Absorption and electrochemical data of Ru-T1, Ru-T2, Ru-T3. and N.3.

\begin{tabular}{|c|c|c|c|c|}
\hline \multirow{2}{*}{ Complex } & \multicolumn{3}{|c|}{ Absorption coetficient $\left[{ }^{*} 10^{3} \mathrm{M}^{1} \mathrm{~cm}{ }^{1}\right]$} & \multirow{2}{*}{$110 \mathrm{MO} / \mathrm{LUMO}[\mathrm{LV}]^{t}$} \\
\hline & $\varepsilon_{1}\left(\lambda_{n !: x 1}\right)$ & $\mathrm{C}_{2}\left(\lambda_{\text {nा: } 1 x_{2}}\right)$ & $\theta_{3}\left(\lambda_{\text {m1ax }}\right)$ & \\
\hline N3 & $56.7(311 \mathrm{~nm})$ & $17.5(386 \mathrm{~nm})$ & $16.6(532 \mathrm{~nm})$ & $-5.52 /-3.84$ \\
\hline Ru-Tl & $30.4(30111113)$ & $22.8(368 \mathrm{~mm})$ & $14.1(529 \mathrm{~nm})$ & $-501 /-3.05$ \\
\hline RแL-T2 & $43.4(300 \mathrm{~mm})$ & $28.8(4.45 \mathrm{~nm})$ & $16.8(551 \mathrm{~mm})$ & $-4.87 /-2.95$ \\
\hline Rul-Ti & $456(305 \mathrm{~nm})$ & $31.5(388 \mathrm{~nm})$ & $27.6(563 \mathrm{~nm})$ & $-4.86 /-2.95$ \\
\hline
\end{tabular}

"HOMO is determined from onset of oxidation polentials and LUMO is calculaled from HOMO and band gap. which is derived from the absorption onsel was elengill.

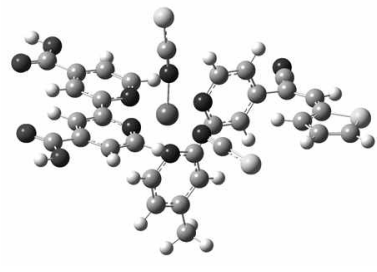

$\mathrm{T} 1(0)$

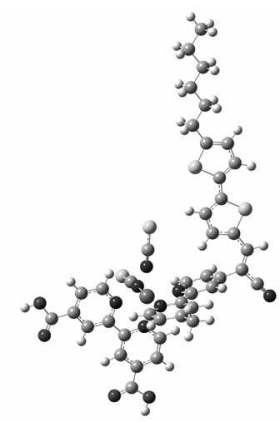

T2 (0)

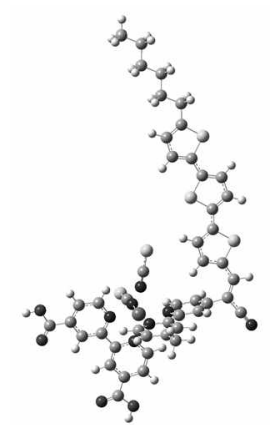

$\mathrm{T} 3(0)$

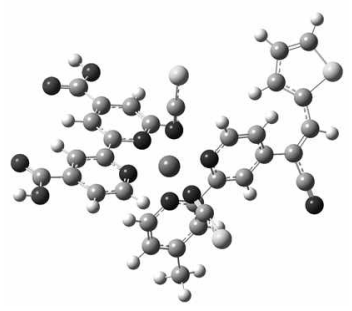

T1' (4.87)

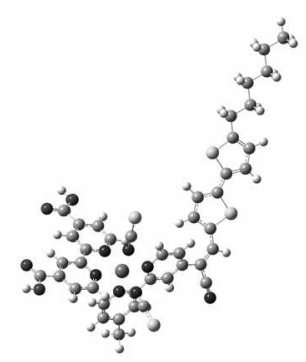

T2' (4.68)

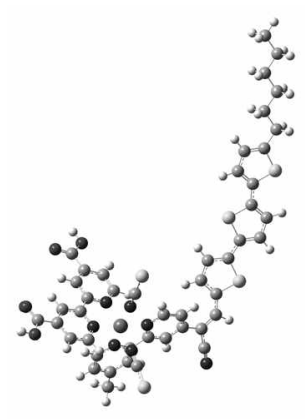

T3' (4.85)
Figure 4. B3LYP/3-2lG;* optimized structures lor $\mathrm{L}^{3}, \mathrm{~L}^{2}$, and $\mathrm{L}^{3}$, l'he values in the parentheses are relative stabilities with respect to the $T$ contomers.

Ru-T1, Ru-T2. and Ru-T3 was approximated by subtracting the optical band gap from the HOMO value and these values are listed in Table 1 . The results confirmed the thermody namic farorability of electron injection from the excitcd Ru-T1 $\sim$ T3 sensitizers into the conduction band of $\mathrm{TiO}_{2}=1$

The geometry optimization for the three sy nthesized $L^{\prime} . L^{2}$, and $\mathrm{L}^{3}$ are carricd out by the density functional theory (DFT) calculations employ ing the Beckes s threc parameters employing Lee-Yang-Parr exchange functional (B3LYP) with 3-21 G* basis sets using a suite of Gaussian 03 programs. "Each compound can be classificd into two conformations depending on the orientation of the thiophene moicties. More precisely, for all $\mathrm{L}^{\mathrm{l}}, \mathrm{L}^{2}$, and $\mathrm{L}^{3}$, the $\mathrm{T} / \mathrm{T}^{*}$ compound denotes the complex. in which the NCS and the thiophene ligand are arranged in different/same direction as shown in Figure 4 . The T conformers of $\mathrm{L}^{1}$. $\mathrm{L}^{2}$. and $\mathrm{L}^{3}$ were more stable than the $\mathrm{T}^{*}$ conformers by 4.68 $4.87 \mathrm{kcal} / \mathrm{mol}$. This stability difference was primarily attributed to two factors: (1) the hydrogen atom in thiophene ring interacts with the sulfur atom of the $-\mathrm{N}=\mathrm{C}=\mathrm{S}$ group and the distance between hydrogen and sulfur atoms is $2.84 \mathrm{~A}$. (2) the other lydrogen atom located on the pyridine ring planc interacts with the $\pi$-electron. These two non-covalent interactions were considered to be important factors for the superior stability of the T conformers over the T" conformers. On the ofher hand. the energy gap between the HOMO and LUMO levels of the T confonners increased because the HOMO orbital energy decreased due to the hydrogen bonding and $\pi-\mathrm{H}$ interaction. The resulis from a DFT calculation of Ru-T1 $\sim$ T3 are presented in Figure 5. The LUMO was mainly the $\pi^{*}$ 2,2-bipyridine-t. 4'dicarboxylic acid ligand with a considerable amount of $\pi$ backdonation from the $t_{2 y}$ orbital. The LUMO had sizeable contributions from the carbosy lic groups. thereby enhancing the electronic coupling to the $\mathrm{TiO}_{2}$ conduction band states. The HOMO was from an antibonding interaction between the $\mathrm{t} 2 \mathrm{~g}$ orbital of ruthenium and the $\pi$-orbital of NCS. The NCS group pointing in the direction of the electrolyte may have facilitated the reduction of the oxidized dye ( $\mathrm{Ru}^{3+}$ ) through reaction with I, making it particularly suitable for highly efficient DSSCs. The $\pi$-orbitals on the (E)-3-(5-alkyloligothiophen-5-y])-2-(4'-methyl-2,2'-bipy ridin-4-y l)acry lonitrilc ligand have a negligible contribution to $\mathrm{HOMO}$

Figure 6 shows the photocurrent density-voltage $(\mathrm{J}-\mathrm{V})$ curves of a $\mathrm{SnO}_{2}: \mathrm{F}_{\mathrm{TiO}} / \mathbf{R u}_{\mathbf{H}} \mathbf{T 1} \cdots \mathbf{T} 3$ dye/liquid electrolyte/Pt devices under AM $1.5 \mathrm{G}\left(100 \mathrm{~mW} / \mathrm{cm}^{2}\right)$. Table 2 summarizes the photovoltaic propertics of the DSSCs using Ru-T1 - T3 and N3 for comparison. Among the three cells, the cell fabricated with Ru-T2 lad highest efficiency of aboul $2.84 \%\left(\mathrm{~V}_{\infty}=0.57 \mathrm{~V} . \mathrm{J}_{\mathrm{sc}}=\right.$ $5.3 \mathrm{~mA} / \mathrm{cm}^{2} . \mathrm{FF}=0.75$ ). Despite the higher molar absorption coefficient of Ru-T3, the lower photovoltaic performance of Ru-T3 was due to the lower solubility and low $J_{\text {sc. which was }}$ associated with its bulky ancillary ligand structure and the lesser absorption of Ru-T3 on the porous nc-TiO 2 clectrode. compared to Ru-T1 and Ru-T2. Another factor for low photovoltaic performance was due to the high LUMO energy level of the Ru-T1 T3 sensitizers, which results the low thermodynamic driving 


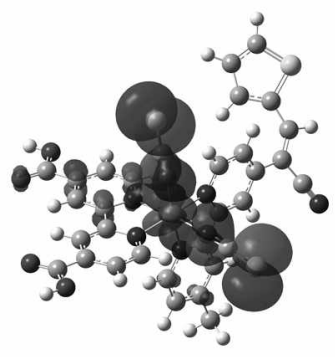

Ru-T1, HUMO (-4.52 eV)

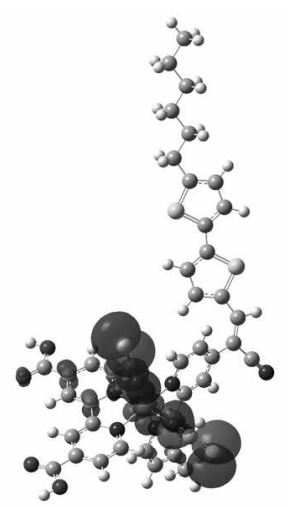

Ru-T2, HUMO (-4.44 eV)

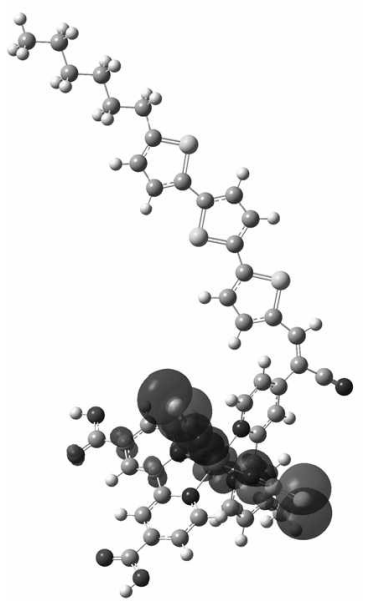

Ru-T3, HUMO (-4.44 eV)

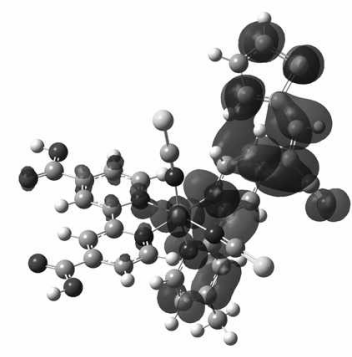

Ru-T1, LUMO (-3.07 eV)

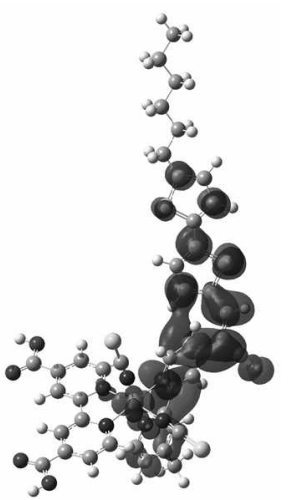

Ru-T2, LUMO (-3.05 eV)

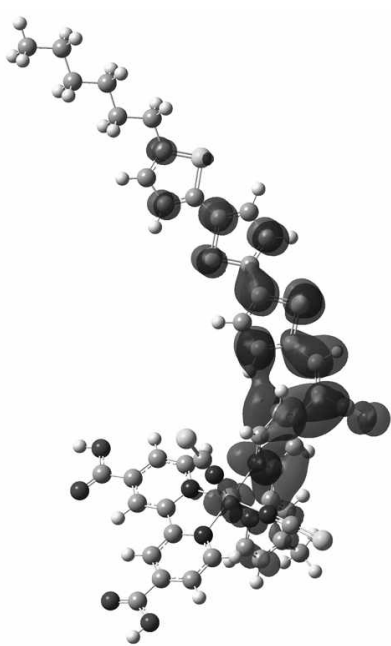

Ru-T3, LUMO (-3.08 eV)

Figure 5. Frontier molecular orbitals of Ru-T1, Ru-T2, and Ru-T3 sensitizers.

force for electron injection from the excited stated LUMO level of $\mathbf{R u}-\mathbf{T 1} \sim \mathbf{T 3}$ sensitizers to the conduction band of $\mathrm{TiO}_{2}$ relative to N3 dye. Further optimization of the liquid electrolyte components or the introduction of scattering layers should improve the photovoltaic performance of the DSSCs.

\section{Conclusions}

We synthesized three novel. heteroleptic ruthenium sensi-

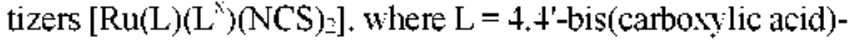
2,2'-bipyridine and $L^{x}$ is (E)-2-(4'-methy l-2.2'-bipyridin-4-yl)3 -(thiophen-2-yl)acrylonitrile or (E)-3-(5'-hexyl-2.2'-bithiophen-5-yl)-2-(4'-methyll-2.2'-bipyridin-4-yl)acrỵ lonitrile or (E)-

Table 2. Photovoltaic parameters of dye-sensitized solar cells with Ru-T1, Ru-T2, Rul-T3 and N3

\begin{tabular}{cccccc}
\hline Sensitizer & $\begin{array}{c}\mathrm{J}_{\text {sic }} \\
\left(\mathrm{mA} / \mathrm{cm}^{2}\right)\end{array}$ & $\begin{array}{c}\mathrm{V}_{\mathrm{oc}} \\
(\mathrm{V})\end{array}$ & $\begin{array}{c}\text { Fill Factor } \\
(\%)\end{array}$ & $\begin{array}{c}\text { Efticiency } \\
(\%)\end{array}$ & $\begin{array}{c}\text { Area } \\
\left(\mathrm{cm}^{2}\right)\end{array}$ \\
\hline Ru-Tl & 6.0 & 0.58 & 70 & 2.45 & 0.21 \\
Rul-T2 & 5.3 & 0.57 & 75 & 2.84 & 0.21 \\
Ru-T3 & 4.5 & 0.54 & 76 & 1.85 & 0.21 \\
N3 & 15.1 & 0.64 & 67 & 6.5 & 0.21 \\
\hline
\end{tabular}

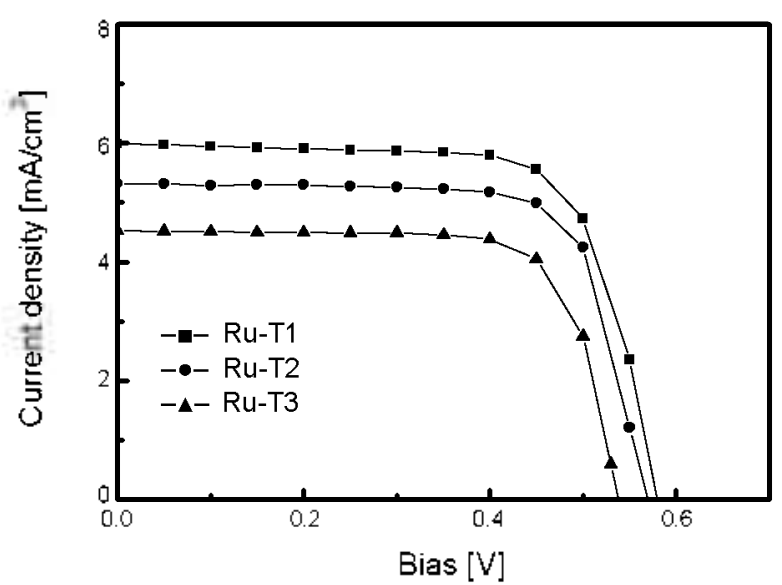

Figure 6. Current density-voltage curves of DSSCs prepared with $\mathrm{TiO}_{2}$ films impregnated with Ru-T1, Ru-T2, and Ru-T3 in DMF.

4-(1-cyano-2-(5"-hexyl-2.2':5'.2"-terthiophen-5-yl)-2.2'-bipyridine. We fabricated the DSSCs with a configuration of $\mathrm{SnO}_{2}$ : $\mathrm{F} / \mathrm{TiO}_{2}$ /ruthenium dye/liquid electrolyte/Pt devices using these Ru-T1 - T3 complexes as sensitizers. Ru-T1 - T3 had a Jsc of 6.0. 5.3 and $4.5 \mathrm{~mA} / \mathrm{cm}^{2}$ and also showed a PCE of 2.45 .2 .84 and $1.85 \%$ with a $\mathrm{Voc}$ of $0.58,0.57$ and $0.54 \mathrm{~V}$. respectively.

Acknowledgments. This work was supported by the Korea Science and Engineering Foundation (KOSEF) grant funded by the Korea government (MEST) (No. 10600000157-06J000015710 and R11-2008-088-01-003-0).

\section{References and Notes}

1. Bilgen, S.; Kaygusuz, K.; Sari, A. Energy Sources 2004, 26 , 1119 .

2. O'Regan, B.: Gratzel, M. Namure 1991, $353,737$.

3. Nazeeruddin, M. K; Kay, A.; Rodicio, I ; Humphry-Baher, R: Muller, E; Liska, P; Vlachopoulos, N.; Gratzel, M. $J$. Am. Chem. Soc. $1993,115,6382$.

4. Nazeeruddin, M. K.; Pechy, P.: Renouard, T.: Zakeeruddin, S. M.: Humphry-Baker, R.; Conte, P.; Liska, P.; Cevey, L.; Costá, E.; Shklover, V:; Spiccia, L.; Deacon, G. B.; Bignozzi, C. A.; Gratzel, M. J. Ant Chen Soc. 2001, 123, 1613.

5. Ushiroda, S.: Ruzycki, N.: Lu, Y.: Spitler, M. T.: Parkinson, B. A. J.Am. Chem Soc. 2005, 127.5158.

6. Horiuchi, T; Miura, M.; SumioKa, K; Uchida, S. J. Am. Chem. Soc. 2004, 126, 12218.

7. Wang, Z. S.; Yamaguchi, T.; Sugihara, H.; Arakawa, H. Langmin. 2005. 21.4272

8. Nazeeruddin, M. K.; Zakeenuddin, S.; Humphry-Baker, R; Jirousek, M; Liska, P.; Vlachopoulos, N.; Shklover, V; Fischer, C. H.; Gratzel, M. Whorg. Chent. 1999, 38, 6298. 
9. Nazeruddin, M. K.; Angelis, F. D.: Fantacei, S.: SElloni, A.: Viscardi, G.: Liska, P.: Ito, S.; Takeru, B.; Grätzel, M.J.Am. Chem. Soc. 2005, 127, 16835.

10. Nazeenuddin, M. K.; Pechy, P: Grätzel, M. Chem. Comm. 1997, 1705

11. Yanagida, M:; Singh, L. P; Sayana, K:; Hara, K.: Katoh, R.: Islam, A.: Sugihara, H.; Arakawa, H.; Nazeeruddin, M. K.; Grätzel, M. J. Chem. Soc. Dalton Trans. 2000, 2817

12. Sugihara, H.: Singh, L. P.: Sayama, K.: Arakawa, H.: Nazeeruddin, M. K. Grătzel, M. Chem. Lett. 1998, 10, 1005.

13. Renouard, T:; Fallahpour, R. A.: Nazeeruddin, M. K.: HumploryBaker, R;: Gorelsky, S. I:; Lever, A. B. P: Grätzel, M. Ihorg. Chen. $2002,41,367$.

14. Wann, P.: Zakeernddin, S. M.; Moser, T.-E:; Humplry-Baker, R:; Comte, P.; Aranyos, V: Hagfeldt, A.; Nazeeruddin, M. K.; Grätzel. M. Adv Mater. 2004, 16, 1806.
15. Wang. P.: Klein, C.: Humphry-Baker, R.; Comte, P.: Aranyos, V; Hagfeldt, A.; Nazeeruddin, M. K.; Grätzel, M. J. Am. Chent. Soc. 2005, 127, 808 .

16. Abbotto, A.; Barolo, C.; Bellotto, L.: Angelis, F. D.; Grätzel, M:: Manfredi, N.: Marinzi, C.: Fantáci, S.; Yum. I. H.: Nazeeruddin, M. K. Chem. Comm, 2008, 42,5318.

17. Frisch, M. T. Goussian 03, Revision A 1; Gaussian Inc.: Pittsburgh, $\mathrm{PA}, 2003$

18. Kang, M. G.; Kim, K. M.; Ryu, K. S.; Chang, S. H.; Park, N. G.; Hong. J. S.: Kim, K. I. J. Electrochem. Soc. 2004, 151, E257.

19. Raposo, M. M. M.; Fonseca, A. M. C.; Kirsch, G. Tetrahedron 2004, 60, 4071.

20. Klein, C.; Nazeenuddin, M. K.; Di Censo, D.; Liska, P.; Grätzel, M. Inorg. Chem 2004, 43,4216

21. Hagfeldt, A.; Grätzel, M. Chem. Rev. 1995, 95, 49. 